Personalidade Acadêmica Homenageada:

Augustus B. Cochran III (Agnes Scott College)

\title{
A POSSIBILIDADE DE RESPONSABILIZAÇÃO INTERNACIONAL DAS EMPRESAS NOS CASOS DE DESASTRES AMBIENTAIS - UM ESTUDO DE CASO: MARIANA E BRUMADINHO, NO ESTADO DE MINAS GERAIS
}

\section{THE POSSIBILITY OF INTERNATIONAL RESPONSIBILITY OF COMPANIES IN CASES OF ENVIRONMENTAL DISASTERS - A CASE STUDY: MARIANA AND BRUMADINHO IN THE STATE OF MINAS GERAIS}

NATÁLIA DINIZ MARTINS

Acadêmico do curso de Direito - Faculdade do Litoral Paranaense - ISEPE Guaratuba. Guaratuba - PR. E-mail: natalia.diniz.jm@gmail.com

LUCIANO RAITER

Professor Orientador - Faculdade do Litoral Paranaense - ISEPE Guaratuba. Guaratuba - PR. E-mail: lucianoraiter@gmail.com

RESUMO

Em 05 de novembro de 2015, o Brasil assistia perplexo às notícias na imprensa, uma barragem contendo rejeitos oriundos da extração de minérios de ferro havia se rompido, a onda formada por esses rejeitos deixou para trás um rastro de destruição, poluindo os locais por onde passava, levando consigo casas, carros, contabilizando, de acordo com os dados obtidos através do website do Ministério Público, 19 mortes de moradores do Município de Mariana, no Estado de Minas Gerais. Ao todo a destruição afetou não 41 outros Municípios e 3 Reservas Indígenas, 


\section{Personalidade Acadêmica Homenageada:}

Augustus B. Cochran III (Agnes Scott College)

além de causar a degradação de mais de 240 hectares de mata atlântica situados no caminho da onda.

Em 25 de janeiro de 2019, três anos após o incidente de Mariana, a cena veio a se repetir, com proporções ainda maiores, na cidade de Brumadinho, também no estado de Minas Gerais, desta vez os maiores danos foram os relacionados às vidas perdidas, que até o momento somam 241 óbitos confirmados de moradores e funcionários da empresa, isso sem se falar dos danos ao meio ambiente que, apesar de menos expressivos do que os apresentados em Mariana, ainda devastaram a natureza da área percorrida pela onda de rejeitos. Em meio a esse caos, há uma coincidência: ambas as barragens são ligadas a uma mesma empresa nacional, no primeiro caso, a empresa em questão encontrava-se em consórcio com uma grande empresa multinacional do ramo de mineração, já no segundo caso não havia consórcio algum, sendo a empresa nacional a responsável por garantir a segurança dos moradores e trabalhadores atingidos. Assim, surge a questão abordada por este trabalho de pesquisa, haveria algo além da legislação nacional que pudesse ser aplicado ao caso, quando esta se mostra ineficaz ou pune de forma insatisfatória as empresas responsáveis a ponto de não tomarem as precauções necessárias para evitar que uma tragédia dessas proporções voltasse a ocorrer, principalmente quando ainda estava na memória da população a catástrofe de Mariana. Para auxiliar na resposta a este problema de pesquisa, utilizou-se o amparo da pesquisa do professor da Faculdade de Harvard John Gerard Ruggie, que através de princípios norteadores sobre direitos humanos, busca nortear a responsabilização de empresas privadas a fim de se evitar danos a esses direitos. Esses princípios são reconhecidos internacionalmente pela Organização das Nações Unidas como diretrizes básicas que devem ser utilizadas por empresas privadas a fim de nortear seu modelo de negócios. Através disso, foi editado o decreto o 9.571/2018, que estabelece as diretrizes nacionais sobre empresas e direitos humanos. Neste mesmo sentido de proteção, em 2016 foi anunciado pelo Tribunal Penal internacional os novos critérios para a seleção dos casos a serem apreciados pelo órgão que incluiu no rol crimes praticados contra o meio ambiente. Tal medida demonstra grande avanço, vez que não há, até o 
Personalidade Acadêmica Homenageada:

Augustus B. Cochran III (Agnes Scott College)

momento, ramo do Tribunal Penal Internacional dedicado à persecução de crimes contra o meio ambiente.

PALAVRA-CHAVE: Danos ao Meio Ambiente; Responsabilização Internacional; Tragédia de Mariana; Brumadinho.

\section{REFERÊNCIAS}

BRASIL. Constituição da República Federativa do Brasil. Disponível em: $<$ http://www.planalto.gov.br/ccivil_03/constituicao/constituicao.htm>. Acesso em Maio de 2019.

BRASIL. Lei no 9.605, de 12 de Fevereiro de 1998. Disponível em: <http://www.planalto.gov.br/ccivil_03/leis/19605.htm>. Acesso em Maio de 2019.

DIARIO OFICIAL DA UNIÃO. Decreto no 9.571, de 21 de novembro de 2018. Disponível em:

$<$ http://www.in.gov.br/materia//asset_publisher/Kujrw0TZC2Mb/content/id/51283321/do1-2018-11-22-decreto-n-9571-de-21-de-novembro-de-2018-51283123>. Acesso em Junho de 2019.

DOWBOR. Ladislau. John Gerard Ruggie. Just Business: Multinational Corporations and Human Rights - W.W. Norton, New York, 2013, 225 p. Disponível em: $<$ http://dowbor.org/2013/10/john-gerard-ruggie-just-business-multinationalcorporations-and-human-rights-w-w-norton-new-york-ouctober-2013-3p.html/>. Acesso em Junho de 2019.

LEHMEN, Alessandra. Julgamento de Crimes Ambientais pelo TPI é marco histórico no Direito Ambiental. Disponível em: <https://www.conjur.com.br/2016out-16/julgamento-crimes-ambientais-tpi-marco-historico>. Acesso em Junho de 2019.

LEITE, José Rubens Morato. Dano Ambiental: Do Individual ao Coletivo Extrapatrimonial. 2 ed. rev., atual. e ampl. - São Paulo: Editora Revista dos Tribunais, 2003.

MINISTÉRIO DA MULHER, DA FAMÍLIA E DOS DIREITOS HUMANOS. Decreto Estabelece as Diretrizes Nacionais Sobre Empresas e Direitos Humanos. Disponível em: <https://www.mdh.gov.br/todas-as-noticias/2018/novembro/decretoestabelece-as-diretrizes-nacionais-sobre-empresas-e-direitos-humanos>. Acesso em Junho de 2019. 
Personalidade Acadêmica Homenageada:

Augustus B. Cochran III (Agnes Scott College)

MINISTÉRIO PÚBLICO FEDERAL. O Desastre. Disponível em: <http://www.mpf.mp.br/grandes-casos/caso-samarco/o-desastre>. Acesso em Maio de 2019.

SILVA, Geraldo Eulálio do Nascimento e. Direito Internacional Ambiental. 2. ed., rev. e atualizada. Rio de Janeiro: Thex Ed., 2002.

UNITED NATIONS. The UN Guiding Principles On Business And Human Rights: Relationship to UN Global Compact Commitments. Disponível em: <https://www.unglobalcompact.org/docs/issues_doc/human_rights/Resources/GPs GC\%20note.pdf>. Acesso em Junho de 2019.

VENTURI, Eliseu Raphael. Proteção, Respeito e Reparação de Direitos Humanos na Atividade Empresarial: Os Princípios do Relatório Ruggie (2011) e a Candente Questão dos Deveres Positivos (Prestação). Revista Jurídica UNICURITIBA. Disponível

em: $<$ http://revista.unicuritiba.edu.br/index.php/percurso/article/view/2594>. Acesso em: Junho de 2019. 